\title{
A survey of patient satisfaction with obstetric anaesthesia service in Tuen Mun Hospital, Hong Kong
}

\author{
Yeung Joanne Tsui Ting ${ }^{1^{*}}$, Cheung Chuen Ho Victor ${ }^{2}$, Chan Pui Lan Rowena ${ }^{3}$ \\ Resident $^{{ }^{*}}$, Associate Consultant ${ }^{2}$, Consultant ${ }^{3}$, Department of Anaesthesia and Intensive Care Unit, Tuen \\ Mun Hospital, Hong Kong
}

\begin{abstract}
Patient satisfaction is an important healthcare performance indicator that has come to the forefront in recent years. Although patient satisfaction surveys have been performed assessing various medical services, there is a lack of survey evaluating patient satisfaction towards the anaesthesia services in Hong Kong. In this study, we looked into the perioperative concerns and patient satisfaction in a group of obstetric patients undergoing anaesthesia for caesarean section (CS) in Tuen Mun Hospital (TMH), which is a large regional hospital in Hong Kong with more than 5500 deliveries per year.
\end{abstract}

Between June 2017 and May 2018, 263 Chinese obstetric patients undergoing elective or emergency CS were recruited into the survey. The median of the satisfaction mark obtained was 139 out of 190. Patients were less satisfied in the aspect of "fear" and "discomfort", which were correlated with severe postoperative pain, general anaesthesia and emergent CS. Improvement in pain management program and alleviating fear and discomfort were recommended. Follow-up survey is recommended to assess the effectiveness of improvement measures. Further patient satisfaction survey can be considered in other patient groups.

Keywords: survey; satisfaction; obstetric; anaesthesia; pain

\section{Introduction}

Patient satisfaction survey provides a valuable source of information to improve the healthcare service quality. Patients' feedback indicates whether things are going in the right direction and helps us to formulate effective quality improvement plans. In Germany, patient satisfaction evaluation has been mandatory since 2005 and plays an important part in the quality management reports. ${ }^{1}$ In the United Kingdom, all hospitals have to perform patient satisfaction surveys on an annual basis since $2002 .^{2}$

*Correspondence: Yeung Joanne Tsui Ting

E mail: joannettyeung@gmail.com

https://orcid.org/0000-0002-6040-6964

Received: 06/08/2019

Accepted: 21/09/2019

DOI: http:/doi.org/10.4038/slja.v28i1.8486



Obstetric patients have high expectations of the health delivery system. Negative obstetric experience may influence the success of breast feeding, leading to postpartum depression and prolonged hospital stay. There are studies looking at maternal satisfaction from their perinatal experience, however, studies regarding pericaesarean section (CS) experience are scanty. 3,4

Patient satisfaction could be related to various factors, including age, school education and marital status, expectations, information given, emotional support, duration of anaesthesia, physical discomfort, perioperative complications, postoperative pain etc. ${ }^{1,25,6}$ A European study showed that most problems were related to 'Information/Involvement in decision-making', and 'Continuity of personal care by anaesthetist'. ' From a published survey in our hospital, post CS patient dissatisfaction was associated with long waiting time in getting the breakthrough dose of analgesia, severe postoperative pain and lack of pain assessment. $^{8}$ 
This study aims at evaluating the patient satisfaction and perioperative concerns regarding the obstetric anaesthesia service in TMH and finding out the attributes that affect the overall patient satisfaction.

\section{Material and methods}

Between June 2017 and May 2018, all Chinese obstetric patients who underwent elective or emergency CS, were recruited into the survey. Written informed consent was obtained. The recruited mothers were interviewed face-to-face by a research assistant or by the principal investigator within 24 hours postoperatively for completion of the questionnaire.

The questionnaire consisted of several parts: a socio-demographic section, 38 questions adopted from the German Heidelberg Peri-anaesthetic Questionnaire-HPQ ${ }^{5}$, maximum pain score within the postoperative 24 hours and an open question for other opinions.

The HPQ is psychometrically designed. It has been validated in a large sample size study at 3 different hospitals with patients of a broad spectrum of risks. It is the first peri-anaesthetic questionnaire tested by a standard pretest and a cognitive method. It has five dimensions, namely: 1 . Trust and atmosphere, 2 . Fear, 3. Discomfort, 4. Treatment by personnel, 5. Information and waiting. Patient establishes a level of agreement with a 5-point Likert scale. The degree of satisfaction is reflected by the total score. As described in the original study of $\mathrm{HPQ}^{5}$, the first quartile of the total score was taken as the cut-off for an insufficient patient satisfaction, which is 132 .

A third phase follow up pain audit (S3) was also performed on postoperative day 2 or 3 (D2/3) to study the patients' opinion and satisfaction on pain management, similar to the 2014-2015 study performed in $\mathrm{TMH}^{8}{ }^{8}$

\section{Statistical analysis}

SPSS software version 21 was used for statistical analysis. Univariate analysis was carried out between satisfaction values and for clinical and sociodemographic characteristics. Linear association was determined through the Spearman's correlation coefficient. As appropriate, MannWhitney $U$ test and the Kruskal Wallis test were used to assess significance of the difference between satisfaction values and qualitative variables. P-value less than 0.05 would be considered as statistically significant.

\section{Results}

Our study recruited 263 Chinese post CS patients. 42 subjects were excluded due to missing data in the HPQ.

\section{Part 1. Patient's demographic data}

Majority of patients were ASA $1(65.8 \%, n=144)$ and only 6patients $(2.7 \%)$ were classified as ASA 3. Most patients had secondary school education level $(69.9 \%, \mathrm{n}=144)$ and were married $(94 \%, \mathrm{n}=188)$. Half of them were housewives $(51.4 \%, \mathrm{n}=107)$ and the rest were working women $(48.6 \%, \mathrm{n}=101)$. There were more emergency cases $(56.6 \%, \mathrm{n}=125)$ than elective cases $(43.4 \%, n=96)$. Number of gravidities of the participants ranged from 1 to 6 , with a median of 2 , and the number of parities ranged from 1 to 5 (including the baby born in this admission), with a median of 1 . Median number of past CS done was one.

Most of the patients had CS performed under spinal anaesthesia (SA) $(78.7 \%, \mathrm{n}=174)$, while others had general anaesthesia (GA) $(11.8 \%, n=26)$, epidural anaesthesia $(5.9 \%, n=13)$ or combined spinal epidural anaesthesia $(2.3 \%, n=5)$. A total of 3 cases (1.4\%) needed to convert from regional anaesthesia (RA) to GA intraoperatively. The median operative time was 53 minutes (range 15-152 minutes).

\section{Part 2. Overall satisfaction}

Satisfaction median score as 139 out of 190, ranging from 102 to 185 . 


\section{Factors affecting overall satisfaction}

Table 1: Univariate analysis of clinical and demographic characteristics and the postoperative HPQ total score

\begin{tabular}{|c|c|c|c|c|c|}
\hline \multirow[t]{2}{*}{ Parameter } & \multirow[t]{2}{*}{ Category } & \multirow[t]{2}{*}{$\mathbf{n}$} & \multicolumn{2}{|c|}{ HPQ total score } & \multirow{2}{*}{$\begin{array}{l}\mathbf{P} \\
\text { value }\end{array}$} \\
\hline & & & Median & $\begin{array}{l}\text { Interquartile } \\
\text { range }\end{array}$ & \\
\hline \multirow[t]{4}{*}{$\begin{array}{l}\text { Education } \\
\text { level }\end{array}$} & $\begin{array}{l}\text { Primary } \\
\text { school }\end{array}$ & 1 & 168 & $168-168$ & 0.297 \\
\hline & $\begin{array}{l}\text { Secondary } \\
\text { school }\end{array}$ & 144 & 138 & $130-151$ & \\
\hline & $\begin{array}{l}\text { Bachelor's } \\
\text { degree }\end{array}$ & 55 & 141 & $134-152$ & \\
\hline & $\begin{array}{l}\text { Master or } \\
\text { above }\end{array}$ & 6 & 136.5 & $135-140$ & \\
\hline \multirow[t]{2}{*}{ Occupation } & Housewife & 107 & 141 & $132-152$ & 0.259 \\
\hline & Working & 101 & 138 & $131-148$ & \\
\hline \multirow{3}{*}{$\begin{array}{l}\text { Marital } \\
\text { status }\end{array}$} & Single & 10 & 138 & $133-141$ & 0.528 \\
\hline & Married & 188 & 140 & $132-152$ & \\
\hline & Divorced & 2 & 134 & $132-136$ & \\
\hline \multirow{2}{*}{$\begin{array}{l}\text { History of } \\
\text { GA }\end{array}$} & No & 146 & 139 & $132-149$ & 0.864 \\
\hline & Yes & 75 & 139 & $131-152$ & \\
\hline \multirow{2}{*}{$\begin{array}{l}\text { History of } \\
\text { SA }\end{array}$} & No & 140 & 138 & $129-148$ & 0.029 \\
\hline & Yes & 81 & 141 & $134-152$ & \\
\hline \multirow{2}{*}{$\begin{array}{l}\text { Anaesthetic } \\
\text { method }\end{array}$} & GA & 26 & 135 & $128-139$ & 0.016 \\
\hline & RA & 195 & 140 & $133-151$ & \\
\hline \multirow{2}{*}{$\begin{array}{l}\text { Conversion } \\
\text { of } \\
\text { anaesthetic } \\
\text { technique }\end{array}$} & No & 218 & 139 & $132-150$ & 0.863 \\
\hline & Yes & 3 & 139 & $129-149$ & \\
\hline \multirow[t]{3}{*}{ ASA } & 1 & 144 & 138 & $130-148$ & 0.156 \\
\hline & 2 & 69 & 140 & $134-155$ & \\
\hline & 3 & 6 & 145 & $141-169$ & \\
\hline \multirow{2}{*}{$\begin{array}{l}\text { Urgency of } \\
\text { operation }\end{array}$} & Emergency & 125 & 138 & $130-149$ & 0.152 \\
\hline & Elective & 96 & 141 & $133-151$ & \\
\hline \multirow{2}{*}{$\begin{array}{ll}\text { Postop } & 24 \mathrm{hr} \\
\text { max } & \text { pain } \\
\text { score } & \end{array}$} & $<7$ & 147 & 141 & $133-154$ & 0.011 \\
\hline & $\geq 7$ & 65 & 136 & $131-144$ & \\
\hline
\end{tabular}

From our study, previous experience with SA was associated with higher HPQ score (median 141 vs. $138, \mathrm{p}=0.029$ ). Besides, higher score was associated with the use of RA median 140 vs. 135, $\mathrm{p}=0.016$ ). The total score was also positively correlated with the number of CS done before $(p=0.031)$. As expected, higher maximal pain score was statistically significantly associated with poorer satisfaction score.

Table 2: Spearman's correlation between clinical variables and HPQ total score

\begin{tabular}{llll}
\hline & \multicolumn{3}{c}{ Total Score of Q1 to Q38 } \\
& $\mathrm{N}$ & $\begin{array}{l}\text { Correlation } \\
\text { Coefficient }\end{array}$ & $\begin{array}{l}\text { Significance(2- } \\
\text { tailed) }\end{array}$ \\
\hline Gravidity & 212 & 0.078 & 0.26 \\
$\begin{array}{l}\text { Parity } \\
\text { Number of previous } \\
\text { caesarean section }\end{array}$ & 212 & 0.093 & 0.177 \\
$\begin{array}{l}\text { Operation time } \\
\begin{array}{l}\text { Postop 24hr max pain } \\
\text { score }\end{array}\end{array}$ & 214 & 0.149 & $\mathbf{0 . 0 3 1}$ \\
\hline
\end{tabular}

\section{Part 3. Individual dimension of satisfaction}

Table 3: Results for each dimension in HPQ questionnaires

\begin{tabular}{ll}
\hline Dimension & $\begin{array}{l}\text { Mean total score divided by number of } \\
\text { items }\end{array}$ \\
\hline Trust and atmosphere & 4.23 \\
Fear & $\mathbf{3 . 0 4}$ \\
Discomfort & $\mathbf{3 . 5 0}$ \\
Treatment by personnel & 4.19 \\
Information and & 3.94 \\
waiting & \\
\hline
\end{tabular}

In our study, it was shown that the score of 'fear' and 'discomfort' ranked lowest among the 5 dimensions (Table 3).

Table 4: Fear score according to sociodemographic and clinical variables

\begin{tabular}{|c|c|c|c|c|c|}
\hline \multirow[t]{2}{*}{ Parameter } & \multirow[t]{2}{*}{ Category } & \multirow[t]{2}{*}{$\mathbf{N}$} & \multicolumn{2}{|c|}{ Fear score* } & \multirow{2}{*}{$\begin{array}{l}P \\
\text { value }\end{array}$} \\
\hline & & & Median & $\begin{array}{l}\text { Interquartile } \\
\text { range }\end{array}$ & \\
\hline \multirow[t]{4}{*}{$\begin{array}{l}\text { Education } \\
\text { level }\end{array}$} & $\begin{array}{l}\text { Primary } \\
\text { school }\end{array}$ & 1 & 19 & $19-19$ & \multirow[t]{4}{*}{0.827} \\
\hline & $\begin{array}{l}\text { Secondary } \\
\text { school }\end{array}$ & 144 & 18 & $14-21.5$ & \\
\hline & $\begin{array}{l}\text { Bachelor } \\
\text { degree }\end{array}$ & 55 & 18 & $15-21$ & \\
\hline & $\begin{array}{l}\text { Master or } \\
\text { above }\end{array}$ & 6 & 16.5 & $15-18$ & \\
\hline \multirow[t]{2}{*}{ Occupation } & Housewife & 107 & 18 & $15-22$ & \multirow[t]{2}{*}{0.367} \\
\hline & Working & 101 & 18 & $15-21$ & \\
\hline \multirow{3}{*}{$\begin{array}{l}\text { Marital } \\
\text { status }\end{array}$} & Single & 10 & 19.5 & $15-20$ & \multirow[t]{3}{*}{0.629} \\
\hline & Married & 188 & 18 & $15-21$ & \\
\hline & Divorced & 2 & 20.5 & $19-22$ & \\
\hline
\end{tabular}




\begin{tabular}{|c|c|c|c|c|c|}
\hline \multirow{2}{*}{$\begin{array}{l}\text { History of } \\
\text { GA }\end{array}$} & No & 146 & 18 & $15-21$ & \multirow[t]{2}{*}{0.924} \\
\hline & Yes & 75 & 18 & $14-22$ & \\
\hline \multirow{2}{*}{$\begin{array}{l}\text { History of } \\
\text { SA }\end{array}$} & No & 140 & 17 & $14-20$ & \multirow[t]{2}{*}{$<0.001$} \\
\hline & Yes & 81 & 19 & $17-23$ & \\
\hline \multirow{2}{*}{$\begin{array}{l}\text { Anaesthetic } \\
\text { method }\end{array}$} & GA & 26 & 15.5 & 14-18 & \multirow[t]{2}{*}{0.02} \\
\hline & RA & 195 & 18 & $15-22$ & \\
\hline \multirow{2}{*}{$\begin{array}{l}\text { Conversion } \\
\text { of } \\
\text { anaesthetic } \\
\text { technique }\end{array}$} & No & 218 & 18 & $15-21$ & \multirow[t]{2}{*}{0.058} \\
\hline & Yes & 3 & 23 & $21-23$ & \\
\hline \multirow[t]{3}{*}{ ASA } & 1 & 144 & 18 & $15-21.5$ & \multirow[t]{3}{*}{0.047} \\
\hline & 2 & 69 & 17 & $14-20$ & \\
\hline & 3 & 6 & 22.5 & $20-24$ & \\
\hline \multirow{2}{*}{$\begin{array}{l}\text { Urgency of } \\
\text { operation }\end{array}$} & Emergency & 125 & 17 & $15-20$ & \multirow[t]{2}{*}{0.026} \\
\hline & Elective & 96 & 19 & $15-22$ & \\
\hline \multirow{2}{*}{$\begin{array}{ll}\text { Postop } & 24 \mathrm{hr} \\
\max & \text { pain } \\
\text { score } & \end{array}$} & $<7$ & 147 & 18 & $15-22$ & \multirow[t]{2}{*}{0.093} \\
\hline & $\geq 7$ & 65 & 17 & $14-20$ & \\
\hline
\end{tabular}

Regarding fear dimension, previous history of SA, current CS performed under SA, high ASA grading and elective operation were all shown to be associated with a higher fear score (i.e. less fear) (Table 4).

Table 5: Spearman's correlation between clinical variables and fear score

\begin{tabular}{llll}
\hline & \multicolumn{2}{l}{ Fear Score* } & \\
& $\mathrm{N}$ & $\begin{array}{l}\text { Correlation } \\
\text { Coefficient }\end{array}$ & $\begin{array}{l}\text { Significance } \\
\text { (2-tailed) }\end{array}$ \\
\hline Gravidity & 212 & 0.138 & $\mathbf{0 . 0 4 5}$ \\
$\begin{array}{l}\text { Parity } \\
\text { Number of previous } \\
\text { caesarean section }\end{array}$ & 212 & 0.223 & $\mathbf{0 . 0 0 1}$ \\
$\begin{array}{l}\text { Operation time } \\
\text { Postop 24hr max pain score }\end{array}$ & 210 & 0.272 & $<\mathbf{0 . 0 0 1}$ \\
\hline
\end{tabular}

On the other hand, increased number of parity, gravidity and number of previous CS were associated with less fear, though the correlation is weak (Table 5).

Concerning discomfort dimension, our study showed that severe postoperative pain was associated with increased discomfort.

\section{Discussion}

\section{Factors affecting overall satisfaction}

We found that patients with history of SA, had SA for current CS and those with good postoperative pain control were more satisfied with the anaesthesia service. The number of previous CS in the range of 0 to 4 was also positively correlated with patient satisfaction.

A likely explanation would be that patients with similar past operative experience would have less uncertainty about the procedure and would usually be more psychologically prepared. This echoed with the findings that patients with increasing number of parities, gravidity and past CS history were associated with less fear. In this sense, patient satisfaction could be improved by providing information about the upcoming procedure, for example, we could provide information leaflets, antenatal talks, videos, small group counselling about C Sand anaesthesiafor all parturients. Therefore, during the peri-CS period, both in anticipated elective or unanticipated emergent fashion, they would be more psychologically prepared for the procedures.

Central neuraxial technique was associated with better performance in 3 dimensions, namely "treatment by personnel", "information and waiting", "fear" and hence a positive overall satisfaction. Under central neuraxial anaesthesia, an awake patient could interact more with the staff throughout the procedure and thus her sense of fear and uncertainty could be alleviated. Immediate skin-to-skin contact with her baby could improve patient satisfaction. RA is the most commonly used technique for CS nowadays. It is associated with less anaesthesia-related maternal mortality ${ }^{9}$, minimal anaesthetic exposure to the neonate, better post-operative pain with neuraxial opioids and RA avoids the risks of maternal aspiration and difficult airway associated with GA. ${ }^{10}$ Therefore, RA should be performed whenever possible for CS and GA should only be considered when absolutely necessary.

Severe pain within the first 24 hours postoperatively was shown to be associated with "discomfort" and had a negative impact on the overall satisfaction. In $\mathrm{TMH}$, a procedure specific pain management programme (PSPMP) was introduced in 2015. ${ }^{8}$ After its implementation, a follow-up audit (S2) demonstrated a more than 50\% reduction in patients with severe pain and a positive increase in patient satisfaction. However, the third follow up pain audit(S3), which was done simultaneously with this survey, showed no significant increase in patients with severe pain but significant increase in D2/3 patient dissatisfaction as compared to the last survey (S2) $(0.7 \%$ in $\mathrm{S} 2$ rose to $1.7 \%$ in $\mathrm{S} 3$ ). Percentage of patient receiving 
patient information leaflets $(64.7 \%$ in $\mathrm{S} 2$ vs $35.3 \%$ in S3), having post-operative pain assessment (89.6\% in $\mathrm{S} 2$ vs $69.2 \%$ in $\mathrm{S} 3)$ and reassessment $(61.3 \%$ in $\mathrm{S} 2$ vs $22.2 \%$ in S3), which were factors correlating with patient satisfaction, dropped significantly in S3. Therefore, apart from designing an effective analgesic regimen, good collaboration between anaesthetists, pain nurses, obstetricians and obstetric ward nurses is required for a holistic pain management program.

To further improve the postoperative pain management, dexamethasone could be introduced into the pain regime with further pain study to evaluate its effectiveness. Systematic review had shown a single dose of intravenous dexamethasone could decrease postoperative pain with no increase in infection or delayed wound healing ${ }^{11}$ and adding dexamethasone to local anaesthetics in trans versus abdomen is plane block could decrease opioid consumption and prolong the time to first request for additional analgesics. ${ }^{12}$ It could also decrease the incidence of postoperative nausea and vomiting.

Surprisingly, patient satisfaction was not decreased by intraoperative conversion of RA to GA nor prolonged operating time. It is postulated that as long as the patient is well informed of the reasons for conversion to GA and long procedure, they will generally accept the decision.

\section{Different dimensions of satisfaction \\ Fear}

Psychosocial stressors produce immunological dysregulation through the immune-brain loop, acting via the same pathways that produce the surgical stress response. ${ }^{13}$ Psychological distress and anxiety perioperatively contribute to greater postoperative pain, delayed recovery, postoperative complications, and impaired wound healing. ${ }^{14}$ It may affect the success of breast feeding, increase the risk of postpartum depression and increase the length of hospital stay. ${ }^{3,4}$

Providing more psychological intervention or support for patients may alleviate perioperative fear, for example as simple as providing sensory information (i.e. what the perioperative experience will feel like) or providing procedural information (i.e. details regarding all aspects of the patient's surgery). ${ }^{15}$

From our survey, less fear was associated with increasing past obstetric experience and elective CS, which reflected that these groups of patients were psychologically better prepared than the nulliparous or emergency group.

\section{Discomfort}

Within the "discomfort" dimension, we included several items, namely thirst, cold and shivering, nausea and vomiting, pain, pruritus, sore throat, muscle weakness and tiredness. These unpleasant symptoms could be reduced by pharmacological or non-pharmacological measures, for example, providing active and passive warming device perioperatively to alleviate cold and shivering; prophylactic antiemetic or ensuring euvolemia and pain free to decrease nausea and vomiting etc.

From our survey, intraoperative discomfort was associated with severe postoperative pain (pain score $\geq 7$ ), and high pain score was associated with lower overall total HPQ score $(\mathrm{p}=0.023)$.

\section{Limitations of our study}

Limitations of our study mainly come from the questionnaire design and validation. Firstly, the questionnaire used was only validated in Germany and it had not been used in the obstetric patients. Direct translation to Chinese with mild modification to accommodate the obstetric patient group was done, therefore the Chinese version had not been validated. Although without validation, the results from this study are generally coherent with previous satisfaction surveys and we can regard this as a pilot study to aid future audits on peri-anaesthetic service in Chinese population.

Second problem encountered when using the HPQ is that, some questions in the "discomfort" dimension are only specific to GA, e.g. sore throat and hard to breathe. As the majority of caesarean sections were done under RA, questions such as intraoperative nausea and vomiting, cold and shivering, or pruritus were included instead. Although the questionnaire was also validated in the patients with sole $\mathrm{RA}^{5}$, it may be more suitable for patients with GA. Future survey may consider giving 2 different sets of questions for GA or RA for better interpretation of results. 


\section{Conclusion}

Our study showed that there is room for improvement in our obstetric anaesthesia service. Fine adjustment of postoperative pain management, alleviation of fear and discomfort, increase in pain assessment and reassessment and provision of patient information leaflets are modifiable factors that may improve outcome. Multidisciplinary teamwork between the anaesthetic and obstetric unit is important to improve obstetric patient satisfaction. Further follow-up survey can be done in future to assess the effectiveness of respective improvement measures.

\section{References}

1. Tonio S, Joerg K, Joachim K. Determinants of patient satisfaction: a study among 39 hospitals in an in-patient setting in Germany. International Journal for Quality in Health Care, 2011; 23(5): 503-9.

https://doi.org/10.1093/intqhe/mzr038

PMid:21715557

2. Crispin, J., Angela, C. \& Stephen, B. The Picker Experience Questionnaire development and validation using data from in-patient surveys in five countries, international journal of quality in Health Care2002;14(5):353-8.

https://doi.org/10.1093/intqhe/14.5.353 PMid:12389801

3. Pagenkopf, D., Davies, J. M., Bahan, M., \&Cuppage, A. A complementary approach to outcome analysis in the parturient. International Journal for Quality in Health Care 1991;3(4),241-245. https://doi.org/10.1093/intqhe/3.4.241

4. Alfaro Blazquez, R., Corchon, S., \& Ferrer Ferrandiz, E. Validity of instruments for measuring the satisfaction of a woman and her partner with care received during labour and childbirth: Systematic review. Midwifery 2017; 55: 103-112. https://doi.org/10.1016/j.midw.2017.09.014 PMid:28992553

5. J. H. Schiff, A. S. Fornaschon, S. Frankenhauser et al. The Heidelberg Peri-anaesthetic Questionnairedevelopment of a new refined psychometric questionnaire. Journal of the Association of Anaesthetists of Great Britain and Ireland 2998; 63(10):1043-1162.

https://doi.org/10.1111/j.1365-2044.2008.05576.x PMid:18717664

6. P.S. Myles, D. L. Williams, M. Hendrata et al. Patient satisfaction after anesthesia and surgery: results of a prospective survey of 10811 patients. British Journal of Anaesthesia 2000; 84(1): 6-10. https://doi.org/10.1093/oxfordjournals.bja.a013383 PMid:10740539

7. T. Heidegger, Y. Husemann, M. Nuebling et al. Patient satisfaction with anaesthesia care: development of a psychometric questionnaire and benchmarking among six hospitals in Switzerland and Austria. British Journal of Anaesthesia 2002; 89(6):

$863-72$.

https://doi.org/10.1093/bja/aef277

PMid:12453931

8. RPL Chan, WS Chan. Outcome following introduction of a procedure specific pain management programme for caesarean section. Sri Lankan Journal of Anaesthesiology 2018; 26(1): 3944.

https://doi.org/10.4038/slja.v26i1.8257

9. Cooper GM, McClure JH. Maternal deaths from anaesthesia. An extract from Why Mothers Die 2000-2002, the Confidential Enquiries into Maternal Deaths in the United Kingdom. Chapter 9: Anaesthesia. Br J Anaesth 2005; 94: 417-23 https://doi.org/10.1093/bja/aei066 PMid:15758081

10. Mark Rollins Jennifer Lucero. Overview of anesthetic considerations for Cesarean delivery. British Medical Bulletin1 March 2012;101(1): 105125

https://doi.org/10.1093/bmb/ldr050 PMid:22219238

11. N. H. Waldron, C. A. Jones, T. J. Gan et al, Impact of perioperative dexamethasone on postoperative analgesia and side-effects: systematic review and meta-analysis. Br J Anaesth. 2013; 110(2): 191-200 https://doi.org/10.1093/bja/aes431 PMid:23220857 PMCid:PMC3544008

12. Donghang Zhang, Dexamethasone added to local anesthetics in ultrasound-guided transversus abdominis plain (TAP) block for analgesia after abdominal surgery: A systematic review and metaanalysis of randomized controlled trials. PLoS One. 2019; 14(1): e0209646. https://doi.org/10.1371/journal.pone.0209646 PMid:30620730 PMCid:PMC6324803

13. Kiecolt-Glaser JK, Page GG, Marucha PT et al. Psychological influences on surgical recovery. Perspectives from psychoneuroimmunology. Am Psychol 1998; 53: 1209-18. https://doi.org/10.1037/0003-066X.53.11.1209 PMid:9830373

14. Pele Banugo and Derek Amoako. Prehabilitation. BJA Education 2017; 17(12): 401-5. https://doi.org/10.1093/bjaed/mkx032

15. Johnston M, Vo" gele C. Benefits of psychological preparation for surgery: a meta-analysis. Ann Behav Med 1993; 15: 245-56. 